\title{
Rio de Janeiro and climate crisis: governance, interactivity and discursive construction on Twitter
}

\author{
Francisca Marli Rodrigues de Andrade \\ Tarssio Brito Barreto \\ Alen Batista Henriques
}

Universidade Federal Fluminense (UFF), Santo Antônio de Pádua - Rio de Janeiro, Brazil

D II Universidade Federal da Bahia (UFBA), Salvador - Bahia, Brazil.

III Universidade Federal Fluminense (UFF), Santo Antônio de Pádua-Rio de Janeiro, Brazil.

\begin{abstract}
The rains that fell on the city of Rio de Janeiro in April 2019 were the heaviest in decades, affecting people's lives in different ways and causing the death of ten people. In the face of the fragility of environmental governance in this region, this study sought to understand how the topic of climate change was addressed on Twitter during an extreme weather event. We performed a thematic analysis of data from tweets posted between 7 and 10 April 2019 retrieved from the Twitter API using an open source R package, yielding 375,000 tweets. Our findings highlight Twitter users' criticism of climate denial in agendas at different levels of government and suggest that new media such as Twitter open up opportunities for repoliticizing climate change and redemocratizing decision-making spaces in the face of climate injustice.
\end{abstract}

Keywords: Rio de Janeiro; Rains; Climate Crisis; Governance; Twitter.

São Paulo. Vol. 23, 2020

Feature Topics: Urbanization, Planning and Climate Change

DOI: http://dx.doi.org/10.1590/1809-4422asoc20190202r2vu2020L6TD 


\section{Introduction}

Evidence demonstrates that climate change poses a host of risks to society, ranging from natural disasters to human migration and species extinction (IPCC, 2007; ROSER; SEIDEL, 2017). Within this context, extreme weather events reveal the disproportionate effects of climate change, exposing environmental injustice and the vulnerability of specific groups and places. Disadvantaged groups such as those living in Rio de Janeiro's favelas, or slums, are particularly exposed to climate hazards, as intersectional inequalities related to gender, race, ethnicity, health, and education make them more vulnerable to climate change. In this regard, the Intergovernmental Panel on Climate Change (IPCC, 2014, WGII, p. 4) defines vulnerability as "the propensity or predisposition to be adversely affected" by climate change, emphasizing the lack of ability to cope and adapt.

On the topic of vulnerability to climate change, the devastating effects of ecological debt have been a burning issue ever since the 1990s, when more than 2,000 scientists and experts from around the world participating in the IPCC assessment process concluded that the Earth's surface had warmed during the twentieth century, presenting "sufficiently clear evidence of the contribution of human intervention to the global warming process" (PORTO-GONÇALVES, 2017, p. 333). Ecological debt has also become a prominent issue in the field of political ecology (MARTÍNEZ-ALIER, 2007). In the context of Brazil, two decades of empirical research conducted by Parikh (1995) show us that minimizing vulnerability and environmental injustice as variants of ecological debt requires us to think about processes of environmental governance:

The notion of governance refers here to forms of steering that are less hierarchical than traditional governmental policy-making (even though most modern governance arrangements will also include some degree of hierarchy), rather decentralized, open to self-organization, and inclusive of non-state actors that range from industry and nongovernmental organizations to scientists, indigenous communities, city governments and international organizations (BIERMANN et al., 2009, p. 4).

The concept of governance has been evoked by a diverse range of professionals and political subjects ever since the 1980s (STOKER, 1998; MARTINE; ALVES, 2019). Within the field of environmental studies, governance represents, among other things, "society's capacity to determine its destiny under a set of conditions (norms, access to information and participation, decision-making rules) that enable the collective [...] democratic management of the course of the state and society" (BORN; PICCHIONI; PAIVA, 2007, p. 22). Within the realm of social organization, environmental governance networks involve, among others, government institutions, civil society organizations, and informational mechanisms (GOMIDES; SILVA, 2009). All of these institutions and political subjects use new social media to produce and spread information about climate change.

Environmental governance is strengthened by democratic claims-making practices, climate change mitigation, adaptation, prevention and risk minimization strategies, and 
collective actions to promote global climate governance (INOUE, 2016; ROSER; SEIDEL, 2017). In this regard, O'Neill and Boykoff (2011, p. 234) highlight that "more recent developments in new media [...] have signalled substantive changes in how people access and interact with information, who has access, and who are the authorized definers or claims makers". We agree that "the complexity and multi-level nature of climate change requires governance systems able to manage and resolve conflicts of interests across multiple scales and among diverse policy actors" (DI GREGORIO et al., 2018, p. 73). Framed within these multiple scales and actors is the power of new social media such as Twitter to expand the production of and access to discourses claiming that the impacts of climate change are the result of ecological debt.

Ecological debt goes hand in hand with disproportionate exposure to risk, that is, climate injustice imposed on vulnerable communities and regions. According to Milanez and Fonseca (2011, p. 84), "the concept of climate justice emerges as an offshoot of the environmental justice paradigm and the perception that the impacts of climate change affect different social groups in different ways and with different intensity". In turn, Acselrad (2013, p. 63) conceptualizes environmental injustice as the "disproportionate exposure to environmental risks of populations less endowed with financial, political and informational resources".

This article looks at a poignant example of climate injustice in Brazil: the disproportionate social and economic impacts of extreme weather events on disadvantaged communities in large cities. We focus on the heavy rains in Rio de Janeiro between 7 and 10 April 2019 - when an astonishing $343.4 \mathrm{~mm}$ of rain fell within just 24 hours on the Rocinha favela ${ }^{1}$ - exploring Twitter users' perceptions of this extreme climatic event and its impacts on the city.

We hypothesize that the discourses produced on Twitter reflect not only users' perceptions of extreme climatic events, but also the power of public participation to strengthen governance $\mathrm{n}$ etworks. In this respect, climate justice is seen to encompass the active participation of social actors adversely affected by climate change at all levels of decision-making (MILANEZ; FONSECA, 2011; LI; CROPANZANO; BAGGER, 2013; ROSER; SEIDEL, 2017). We also argue that climate justice research can help gain a better understanding of ecological debt and contribute to making governments and corporations accountable for the impacts of climate change.

We understand that climate justice encompasses the production of and access to information that is consistent with perceptions of reality based on real experiences and cultural diversity. Both the production of and access to information are key components of systems of governance that seek to reduce environmental injustice, insofar as "social media plays an extremely important role in ensuring that research and sociopolitical decisions become public and that the population has information to confront such risks" (LOOSE; GIRARDI, 2017, p. 157). In clear cases of extreme weather events such as the heavy rains in Rio de Janeiro in April 2019, the production of and access to tweets 
can be seen as tools for promoting citizen empowerment and strengthening democracy, environmental governance, and climate justice networks.

\section{Methodology}

Over the last decade, Twitter has become an important research tool in the academic field, offering a vast range of information and enabling researchers to identify and analyze discourse patterns, behaviors, user sentiment, market movements and the risks, and health issues associated with the $\mathrm{H} 1 \mathrm{~N} 1$ and new coronavirus pandemics (GIUSTINI; WRIGHT, 2014; KOSTKOVA, et al., 2014; SEVERYN; MOSCHITTI, 2015; REBOREDO; UGOLINI, 2018; LOPEZ et al., 2020). In Brazil, different types of users - political leaders, journalists, celebrities, etc. - use Twitter to disseminate information, disinformation and a range of political positions, including those regarding climate change (BALBÉ; CARVALHO, 2017).

Some users, known as "influencers", have the ability to reach a wide audience through their personal profiles or "bots" (FERNÁNDEZ GÓMEZ et al., 2018). The notion of influencer has become "a new model of opinion leadership that combines personal branding with the role of public influencer, including messages with political content" (FERNÁNDEZ GÓMEZ et al., 2018, p. 19). When widely disseminated, this content becomes part of the social imaginary and can therefore either contribute to processes that strengthen environmental governance networks or boost efforts to discredit science and promote climate change denial (LOCKWOOD, 2008; O'NEILL; BOYKOFF, 2011; DI GREGORIO et al., 2018).

Based on the elements presented above, this study is interdisciplinary insofar as it brings together different areas and fields of knowledge traversed by theoretical concepts such as climate change, governance, vulnerability, and climate justice, among others. Using a differentiated methodology, we aim to explore public understanding of extreme weather events as they happen, focusing on the perceptions of users of new media, which have brought about significant changes in communications, making them more interactive and accessible to an ever-widening audience (O'NEILL; BOYKOFF, 2011; BALBÉ; CARVALHO, 2017).

According to Crosbie (2002), new media have three distinguishing characteristics: a) the ability to deliver individualized messages simultaneously to those with access; b) the control of the content shared by each individual involved; and c) the dependence of new media on technology. Twitter, a new media platform, is a social network and microblogging server that allows users to send messages and receive personal updates from other contacts using a limit of 280 characters $^{2}$. The analysis proposed by this study is particularly pertinent for considering three key elements that characterize the role of new media in climate change engagement, as described by O'Neill and Boykoff: 
The first is information. Clearly, new media present individuals with a wealth of previously inaccessible information on an endless variety of topics. [...]. The second key theme is new media interactivity. Web 2.0 technologies give new opportunities to individuals to engage with many others, and create their own online content. [...]. The final theme is that of inclusivity. New media agents may act to enable and enhance contact and engagement between individuals, communities, organizations and others with climate change (O'NEILL; BOYKOFF, 2011, p. 236).

The data used in this study come from tweets on the heavy rains in Rio de Janeiro posted between 7 and10 April 2019 retrieved from the Twitter API using an open source R package. The tweets were retrieved in two stages: 1) An initial search using the following keywords or hashtags: "chuvarj" (rainrj), "chuvasrj" (rainsrj), "temporal” (storm), and "chuva" (rain), yielding 375,000 tweets; 2) These 375,000 tweets were then filtered using the terms "aquecimento global" (global warming) and/or "mudança climática" (climate change), resulting in a sample of 53 tweets $^{3}$.

The 53 tweets were then analyzed using thematic analysis. According to Braun and Clark, thematic analysis is a method for analyzing patterns (themes) across data clearly linked to the overall research question and capable of representing relevant topics with some loss of complexity (BRAUN; CLARK, 2006). This method was used to analyze three core themes: neighborhoods, influencers ${ }^{4}$ and climate change.

\section{Climate Change}

With regard to the theme climate change, the tweets were grouped into six distinct categories based on the discourses present in the messages and theoretical constructs in the literature linked to the overall research question, as shown in Box 1. 
Box 1 - Categories related to climate change

\begin{tabular}{|c|l|}
\hline Category & \multicolumn{1}{|c|}{ Description } \\
\hline Climate change denial & $\begin{array}{l}\text { Tweets that decharacterize and delegitimize scientific } \\
\text { evidence of the existence and impacts of climate change }\end{array}$ \\
\hline Adaptation & $\begin{array}{l}\text { Messages emphasizing the need for actions directed at } \\
\text { climate change prevention, adaptation and mitigation }\end{array}$ \\
\hline Governance & $\begin{array}{l}\text { Discourses that signal and/or criticize government } \\
\text { positions and agendas on climate change }\end{array}$ \\
\hline $\begin{array}{c}\text { Vulnerability } \\
\text { Criticism of climate } \\
\text { skepticism }\end{array}$ & $\begin{array}{l}\text { Tweets highlighting the degree of vulnerability of the } \\
\text { population to extreme weather events }\end{array}$ \\
\hline $\begin{array}{c}\text { Education and } \\
\text { dinformation criticizing actions, agendas, positions and } \\
\text { leaders, institutions, and citizens }\end{array}$ \\
\hline $\begin{array}{l}\text { Discourses emphasizing the need to address climate } \\
\text { change in the information, communication and education } \\
\text { arena }\end{array}$ \\
\hline
\end{tabular}

Source: Authors' elaboration (2019).

Drawing on these categories, this study sought to understand how the topic of climate change was addressed on Twitter during an extreme weather event, highlighting the key terms and commonly recurring themes that distinguish these categories. In doing so, we signify these categories within a set of information that portrays the social, economic and political inequalities in the city of Rio de Janeiro that determine the possibilities of citizen participation in processes that strengthen environmental governance and make disadvantaged groups more vulnerable to climate change.

\section{Results and discussion}

The rains that fell in Rio de Janeiro in April 2019 were the heaviest recorded in the city over the last 22 years and affected the lives of residents in a number of different ways: 10 deaths, landslides, flooding, fallen trees, traffic jams and public transport disruptions, and blackouts, among others. These situations are understood by the public in different ways and discourses surrounding the event on social media reveal these differences in understanding. This is because, at times of intense discourse on climate change on social media "new media offer opportunities for people to get involved in building new communities and making global linkages" (O'NEILL; BOYKOFF, 2011, p. 239). In the present study, these linkages reflect Twitter users' different ideologies and political positions on climate change, as the following figure shows: 
Figure 1- April rains in Rio de Janeiro: themes evoked on Twitter

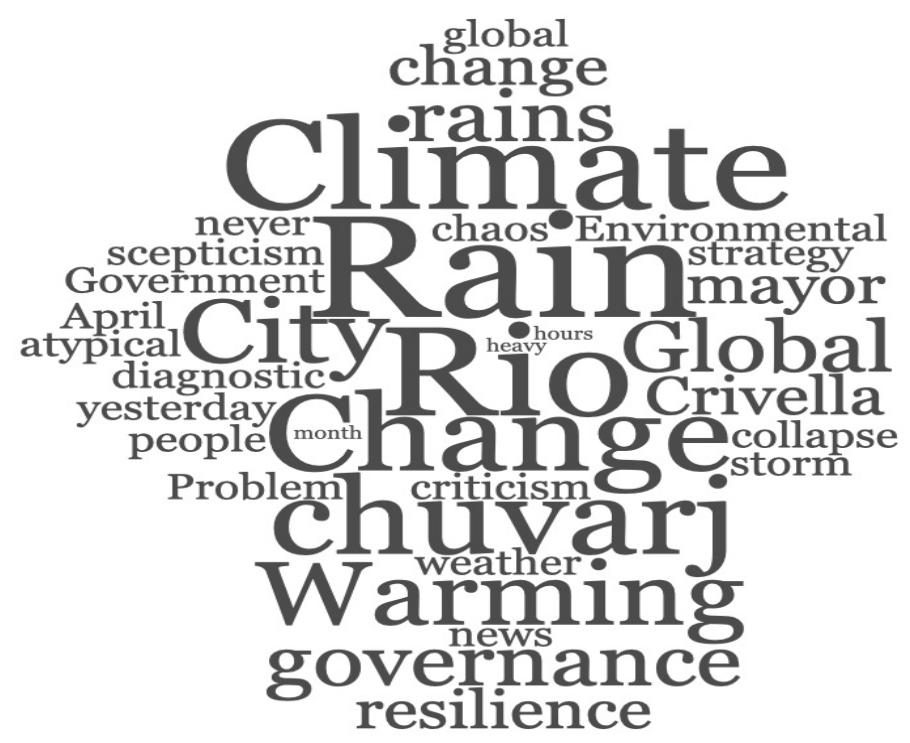

Source: Authors' elaboration (2019).

The most commonly used words in the messages reflect the varying views and perceptions of the event. Words such as "chaos" and "collapsed" indicate negative sentiment, while other terms are linked to environmental and climate governance. These views and perceptions were analyzed under the following categories: a) climate change denial, b) adaptation, c) governance, d) vulnerability, e) criticism of climate skepticism, and $\mathrm{f}$ ) education and information. The categorization of the discourses was not exclusive, with each message exhibiting crosscutting semantic elements and meanings. Each element reflects a particular understanding of the event, which may vary according to the different factors (cultural, informational, and political, among others) that influence users' discourse. The following sections provide a more detailed description of the results by category.

\section{Climate change denial}

While new social media has opened up opportunities for discussing climate change, they also offer a platform for spreading other lines of thinking that seek to decharacterize and delegitimize scientific evidence pointing to human-induced climate change (LOCKWOOD, 2008). For Martine and Alves (2019), climate change deniers include the likes of Donald Trump, Jair Bolsonaro and other populist leaders who delegitimize not only scientific evidence, but also key international bodies. In the view of these authors, "public opinion is more easily swayed by negationist propaganda, because it relieves people of the 
obligation to change their behavior or confront complex issues regarding the prevalent development paradigm" (MARTINE; ALVES, 2019, p. 19). In Brazil, climate change denial continues to be propagated despite extreme weather events, as illustrated by the following tweet:

@exame Crivela, Mirian Leitão and André Trigueiro affirm that the heavy rains in Rio are the result of climate change. They are all charlatans. The only climatologist interviewed on Climatempo denies any association between microclimate phenomena and climate change. (Tw6).

This message delegitimizes the climate change views of the journalists Mirian Leitão and André Trigueiro, resorting to the professional opinion of a climatologist to discredit the crisis. It also reveals the tensions that exist between different positions, reinforcing the argument that "countering such powerful and comforting voices is certainly not an easy task, given the strength and perniciousness of their speakers. Part of the negationist strategy [... involves destroying the credibility and even the personal and professional lives of those who oppose them" (MARTINE; ALVES, 2019, p. 21). This is further illustrated by the following message talking about the journalist André Trigueiro and arguing in favor of climate change denial: “@g1 Regarding G1's post, I've seen a lot of people (like André Trigueiro) blaming climate change for the rains. There is no evidence of that so far. Rains like that have always happened. Look at G1's own report" (Tw4).

Although discourses supporting climate change skepticism make up only a relatively small proportion of the tweets $(9.4 \%)$, our results are consistent with the evidence presented by O'Neill and Boykoff (2011) and Lockwood (2008), who underline that climate change deniers have used new media such as Twitter to expand their follower base. This assertion is reinforced by the following post: “@taliriapetrone, prove that the heavy rains in RJ were due to climate change. Then you will have something to back your claims" (Tw1).

New media are also used to convey messages that sow doubt in the public: "funny, to condemn the mayor they say the rains have been occurring since colonial times, but to defend climate change they omit this statistic saying that they have never happened before... it's difficult!" (Tw9). Although tweets alluding to climate change denial were present in the study data, they were by no means representative of the data overall. As Balbé and Carvalho point out (2017, p. 144), this may be explained by the fact that "discussions [of climate-related issues] tend to be more concentrated among activists than climate change skeptics and deniers".

\section{Adaptation}

The scientific approach to climate change gained prominence in the 1990s. Since then, political leaders, international organizations and other sectors of society have adopted largely conservative measures directed at prevention, adaptation and mitigation (VIOLA; FRANCHINI, 2012; MARTINE; ALVES, 2019). For Murphy et al. (2016, p. 
102), "successful adaptation to climate change will require understanding processes of social and biophysical change and their interactions within socio-ecological systems". Moreover, adaptation will demand a set of well-coordinated actions, agendas and concrete commitments capable of involving citizens in environmental governance processes (JACOBI; SULAIMAN, 2016).

Our results point to failures in environmental governance related to climate change prevention, adaptation and mitigation. The messages highlight that "a combination of urbanization and climate change demands politicians prepared to provide cities with resilience and adaptation. The opposite of this 'new era' with so many idiot authorities elected in the name of God and deniers" (Tw39). This discourse alludes to the need to rethink cities from a resilience perspective, where "Resilience may be considered an emergent property of a system, one that cannot be predicted or understood simply by examining the system's parts. Resilience absorbs change and provides the capacity to adapt to change" (BERKES; COLDING; FOLKE, 2003, p. 5-6). Although this message makes reference to the commitments undertaken by local, state, and federal governments, it contains discursive elements that cut across other categories of analysis. The same meaning can be observed in the following message:

Devastating storms like yesterday's are becoming increasingly common in Rio de Janeiro, due to the intensification of climate change and global warming and the negligence of the local and state public authorities in relation to flood and landslide prevention. \#ChuvaRJ (Tw30).

The absence of climate change prevention and adaptation measures in the city fuels injustice leading to extreme situations such as the one described in the following message: " 3 bodies buried in a taxi just confirmed. The population of Rio de Janeiro needs to be trained for emergency situations. We need infrastructure and we need to understand that this is not going to be an isolated event. \#climatechange is real. \#ChuvaRJ" (Tw33) In relation to tragic situations like the one above, Jacobi and Sulaiman (2016, p. 134) remind us that '“announced disasters' cannot be seen as fatalities, rather in most cases they can be foreseen and avoided". The absence of climate resilience policies highlights two important issues: a) the failure of the government to recognize the imminent risks posed by the climate crisis; and b) the interference of personal beliefs in decision-making. These and other aspects illustrate the "deep dysfunctionality of Brazilian politics in addressing the long-term demands raised by sustainable development, assigning Brazil the characteristics of an underdeveloped environmental power" (VIOLA; FRANCHINI, 2012, p. 4) with very little political will to change the situation. 


\title{
Governance
}

The concept of environmental governance that appears in the tweets reflect a variety of perspectives, each framed within public participation for strengthening democratic processes and the creation of networks and political agendas aimed at undoing environmental and climate injustices (BIERMANN et al., 2009; INOUE, 2016; DI GREGORIO et al., 2018). The study data suggest that governance is a priority among users, with $47 \%$ of the 53 tweets containing discursive elements that fall within this category or, in other words, conveying messages that highlight and criticize the positions and agendas adopted by the different levels of government in relation to the climate crisis. Criticisms include: "the city of Rio is in a state of collapse. And no, it's not the rain's fault. It's Mayor Crivella's fault. A staunch denier, Crivella has ignored the regulatory framework for climate change and resilience for the city. \#chuvasrio" (Tw38). These criticisms gain another meaning in the following tweet:

\begin{abstract}
We are outraged by the mayor of the city of Rio de Janeiro's words. The phenomenon we witnessed today was the effects of climate change. It has nothing to do with "atypical" rains. Preventive measures should be taken, yesterday! \#grevepeloclima \#RiodeJaneiro (Tw13).
\end{abstract}

The tweets make reference to the positions adopted by political leaders, the absence of public policies, and the resulting impacts of the climate crisis on people's lives. These positions include skepticism over scientific evidence, revealing the complexity of crisis in the face of the absence of an environmental governance agenda (VIOLA; FRANCHINI, 2012; INOUE, 2016). For example, some users point out that "The city has a municipal climate change policy, deputy. And it has a resilience strategy. The mayor's denial interferes in management to such an extent that we are in this state of collapse today. See my explanation in this text. \#CPIdasEnchent" (Tw42). Other users highlight that "There is a policy, it's just not used. The city of Rio has a resilience strategy, diagnosis and focus areas with the main threats to the city related to climate change. And yes, today's heavy rains, like those in February, are climate change" (Tw53).

The results reveal the users' perception that there is a strong inclination towards climate change denial on the part of the municipal government. The impacts of this denial are not only ideological. The messages reaffirm the existence of environmental impacts and climate injustice, particularly in regions where democracy is more fragile and, consequently, environmental governance is weaker (VIOLA; FRANCHINI; RIBEIRO, 2013; MARTINE; ALVES, 2019). This is illustrated by the following message: "the city of Rio had a resilience strategy, launched in May 2016 by the former mayor Eduardo Paes. A pioneering strategy [Rio Resiliente] to tackle the effects of climate change and urban challenges. What has \#Crivella done with it? And what has this to do with \#ChuvaRJ?" (Tw10). In short, the messages suggest that discontinuity in climate resilience projects has undermined environmental governance. 


\section{Vulnerability}

The concept of vulnerability has been exhaustively studied in international reports on the climate crisis (IPCC, 2014; BIERMANN et al., 2009). The incorporation of this topic has contributed to revealing the additional difficulties faced by certain regions and populations in relation to environmental problems. For Biermann et al. (2009, p. 59) "the most vulnerable to earth system transformation will be those who live in the marginalized lands". The authors add that "in a socially just society, the distribution of benefits, burdens and involuntary risks is perceived as fair by all of its members and any non-members affected by those allocations. Each person has equal opportunities for education, health or employment" (BIERMANN et al., 2009, p. 59). In Rio de Janeiro, social inequality manifests itself in different ways, including unequal access adequate to education and housing (IBGE, 2010).

The following tweet illustrates the vulnerability experienced by the population: "the minister of the environment, after the death of 10 people in a city in a state of collapse on a crazily hot day with the heaviest rains in 20 years: climate change is less important" (Tw3). This message reveals not only the vulnerability of the city and the irreparable impact of an extreme weather event, but also the user's perception of the importance given to the climate crisis on the federal government's agenda. The messages also make reference to other forms of vulnerability such as psychological vulnerability, manifested in feelings of powerlessness in the face of the absence of the state, as the following tweet illustrates: "this is my old street. Sad to see the state of abandonment of a global city like Rio. The incompetence that plunders our services is a time bomb in a world in deep climate change. \#EcoTrabalhismo \#ChuvaRJ" (Tw11).

The perception of vulnerability goes beyond the extreme weather event, as the following message shows: “@RodCunha It may well be climate change, but I lost count of the clogged culverts BEFORE the rains, not to mention the holes and trees and slopes threatening to fall" (Tw22). These messages place us face-to-face with the reality of abandonment, whereby certain segments of the population are disproportionately exposed to the impacts of ecological debt, social inequalities, and the risks posed by the climate crisis and fragility of democracy. The messages illustrate the different dimensions of the fragility of democracy, especially considering the criticism of the dismantling of environmental policies and agencies by Executive Order No 870 and "the lack of an approach to climate change within the spectrum of roles and responsibilities of the Ministry of the Environment" (ANDRADE, 2019, p. 5). In the view of the users, the environmental agenda is "not just draining Rio, we have to treat climate change seriously! Dissolving Ibama and attacking the Amazon... \#ChuvaRJ" (Tw41). In the same vein, another user highlights the following: "remembering that apart from the lack of infrastructure in Rio, the rains also show that we DON'T GIVE A DAMN about climate change. And it is clear that our government doesn't invest a cent in research related to the environment. \#ChuvaRJ" (Tw36). 


\section{Criticism of climate skepticism}

The results presented reveal the perceptions of users in relation to climate change denial propagated by political leaders (mayors, governors and the president), with 49\% of tweets containing elements criticizing actions, agendas, positions, and discourses that delegitimize the existence of the climate crisis. The following tweet illustrates this criticism: "the Bolsominion chancellor says that climate change due to global warming is a Marxist plot. It doesn't exist my friends, you can believe it, it always rains \#ChuvaRJ" (Tw29). Criticisms of climate change denial in the federal government highlight that "it's just as well that the minister of the environment @ rsallesmma said that climate change is an academic topic. The guys at @ClimaInfoNews were getting worried" (Tw20). Criticisms of the federal government's position on the climate crisis are predominant in the messages analyzed by this study, as illustrated by the following tweet:

In the last 24 hours in Rio de Janeiro, it has simply rained twice as much as the historic average for April. Let's keep on being blind and thinking that these rains are normal, that it has always been like this, that \#climate change is an invention of Marxist culture (Tw31).

This above tweet makes reference to a post made on social media by Brazil's Minister of Foreign Affairs, Ernesto Henrique Fraga Araújo, talking about what he calls "climate change ideology". The criticisms of climate change denial reach beyond the federal government, as the following message shows: "The mayor of Rio says that the chaos was due to 'atypical' rains. If I'm not mistaken, that was the third 'atypical' rainfall in 2019 alone" (Tw16). The meanings in the tweets reveal much more than the users' perceptions of the denial that the April rains were an extreme weather event, clearly reflecting the discontent of part of the population with the environmental policy process, in which politicians' personal beliefs interfere in the governance of the country. Our results show that the positions adopted by political leaders undermine the principle of impersonality, deepening environmental and climate injustice, whereby the costs of ecological debt fall disproportionately on vulnerable places and communities.

The criticism of climate skepticism is also levied against the media, as shown by the following tweet: "In an interview on GloboNews today, @andretrig, president of Clima Tempo, stressed that today's rains have nothing to do with climate change. In fact, the reporter mentioned in the interview that it has been happening in Rio since the XVI century" (Tw24). With regard to climate change in the conventional news media, we agree with Loose and Girardi (2017, p. 166) when they state that "the balance of information rule (giving the same space to sides with opposing opinions) impairs public understanding". For these authors, giving space to those who really study the fact "helps correct understanding and prevents, for example, deniers receiving the same space as the major segment of scientists studying the climate" (LOOSE; GIRARDI, 2017, p. 166). In this regard, the positions adopted by certain users in our study reinforce climate change 
denial. However, our results also point to the existence of movements that contest this view and demand the recognition of the April rains as an extreme weather event on Twitter and the repoliticization of the climate crisis in the sphere of environmental governance.

\section{Education and information}

Over the last decade, new media have caused a veritable decentralization of climate change issues, whereby interacting themes of information, interactivity and inclusivity act to engage wider audiences in discussions (O'NEILL; BOYKOFF, 2011). However, this decentralization has not yet been sufficient to "create and multiply spaces for dialogue and integration that promote processes of governance for the integrated management of public policies, a medium to long-term vision for urban planning, and the construction of participatory processes" (JACOBI; SULAIMAN, 2016, p. 139). In this regard, our results highlight an important question in relation to extreme climatic events: the role played by conventional news media in informing the public about this issue, as illustrated in the following tweet: "they are finally saying on the TV that the rains in Rio are the face of climate change (the media's need to create information about the event)" (Tw18). The importance of the media's role can also be seen in the following message: "@andretrig gave Crivella a lesson on climate change" (Tw44).

Our results also suggest the need for education about the salient features of climate change/global warming: "blaming the council for the chaos yesterday in Rio due to the rains is very legitimate. But you can also stop mocking your friend who asks you to save water, avoid plastic and use the car less. First and foremost, it's climate change. And it can get much worse!” (Tw48). The tweets in this category suggest that environmental education is an important facet of environmental and climate governance: "\#ChuvasRJ It's time for everyone to take responsibility in environmental education, not polluting the rivers and streams, raising awareness about the importance of climate change" (Tw25). Environmental education, as suggested by this user, should go beyond conservative notions, adopting a critical approach to provide an in-depth analysis of the social, economic, political and environmental dimensions of climate change. This is because:

[...] without it, it is not possible to discern the different political-pedagogical proposals that jostle for space in this social field, the different political projects for climate governance, and achieve autonomy to position yourself before them or invent other alternative courses of action (LIMA, 2013, p. 111).

The critical approach to environmental education should reach beyond schools, considering broader possibilities for overcoming current governance challenges. These challenges include the implementation of policies "designed to make cities socially and environmentally sustainable as a way of counterposing deteriorating living conditions and the multiplication of the risks associated with extreme events" (JACOBI; SULAIMAN, 2016, p. 139). However, as the users' perceptions of this issue show, the denial of climate 
change by political leaders will make it difficult to build this governance. Environmental education should play a key role in navigating the climate change minefield, especially considering the repoliticization of the climate crisis, and in encouraging the redemocratization of decision-making processes in different social spaces, including Twitter.

\section{Conclusions}

The Twitter users' perceptions of an extreme weather event in Rio de Janeiro observed by this study provide some important elements to help analyze public understanding of the climate crisis in a context marked by social inequalities. These perceptions offer some possibilities for analysis underpinned by a combination of theoretical and methodological elements framed in an environmental governance perspective. Our findings suggest that, on the one hand, Twitter contributes, albeit to a limited extent, to consolidating social engagement networks in this region, thus strengthening democracy and environmental governance and reducing climate injustice. However, the platform is also used to spread climate change denial, delegitimizing the vast body of scientific evidence on human-induced global warming.

In addition to the above, a number of other implicit and explicit assumptions can be made based on the discourses on Twitter about climate change found by this study. With regard to implicit assumptions, it is important to highlight the apparent invisibility of the problem of climate change on social media even during an extreme weather event, illustrated by the fact that a mere 53 tweets out of a total of 375,000 (0.01\%) mentioned climate change and/or global warming. In this regard, the absence of these terms in messages posted by government bodies, political leaders, and both conventional and alternative news media provide an interesting direction for future research. With regard to explicit assumptions, the tweets analyzed by this study give visibility to the users, illustrating their differing perceptions of the event based on their own experiences and political and ideological positions.

The predominant categories in terms of number of tweets were criticism of climate skepticism and governance, directing severe criticism at the imposition of personal beliefs in public administration, where climate change denial propagated by political leaders undermines the principle of impersonality. In the categories vulnerability and adaptation, the fragility of democracy is a constant, particularly the absence of the state and climate change prevention, resilience and adaptation policies. This fragility is laid bare before a dramatic illustration of climate injustice: deaths, landslides, floods, and the mental health disorders caused by the anxiety and uncertainty generated by the imminent risks of extreme climatic events. To tackle this situation, our findings reinforce the need for education and information to promote public engagement in decision-making processes and strengthen environmental governance. 


\section{References}

ACSELRAD, H. Liberalização da economia e flexibilização das leis - o meio ambiente entre o mercado e a justiça. Revista de Educação, Ciências e Matemática, Rio de Janeiro, v.3, n.3, p. 62-68, 2013.

ANDRADE, F. M. R. Natureza e representações que r-existem: cinco séculos de invasão, apropriação e violência na Amazônia brasileira. Rev. Eletrônica Mestr. Educ. Ambient. Rio Grande, v. 36, n. 2, 207-227, 2019.

BALBÉ, A. D.; CARVALHO, A. As mudanças climáticas no Twitter: a ascendência da mídia e da política. Desenvolv. Meio Ambiente, Curitiba, v. 40, p. 141-161, 2017.

BERKES, F; COLDING, J.; FOLKE, C. Introduction. In: BERKES, F.; FOLKE, C.; COLDING, J. (eds) Navigating social-ecological systems: building resilience for complexity and change. Cambridge University Press, Cambridge, 2003, p. 1-29.

BIERMANN, F. et al. 2009. Earth System Governance: People, Places and the Planet. Science and Implementation Plan of the Earth System Governance Project. Bonn: The Earth System Governance Project, 2009.

BORN, R. H.; PICCHIONI, S.; PIVA, L. Mudanças climáticas e o Brasil. Contribuições e diretrizes para incorporar questões de mudanças de clima em políticas públicas. Brasília, São Lourenço da Serra: Fórum Brasileiro de ONGs e Movimentos Sociais para o Meio Ambiente e o Desenvolvimento (FBOMS), 2007.

BRAUN, V.; CLARKE, V. Using thematic analysis in psychology. Qualitative Research in Psychology, v. 3, n. 2, p. 77-101, 2006.

CROSBIE, V. What is New Media? Disponível em: <http://www.sociology.org.uk/as4mm3a. doc. $>$. Acesso em 28 de julho de 2019.

DI GREGORIO, M., et al. Multi-Level Governance and Power in Climate Change Policy Networks. Global Environmental Change, n. 54, p. 64-77, 2019.

FERNÁNDEZ GÓMEZ, J. D.; HERNÁNDEZ-SANTAOLALLA, V.; SANZ-MARCOS, P. Influencers, marca personal e ideología política en Twitter. Cuadernos.info, n. 42, p. 19-37, 2018.

GIUSTINI, D., WRIGHT, M. D. Twitter: an introduction to microblogging for health librarians. Journal of the Canadian Health Libraries Association/Journal de l'Association des bibliothèques de la santé du Canada, n. 30, v. 1, p. 11-17, 2009.

GOMIDES, J. E.; SILVA, A. C. O surgimento da expressão "Governance", governança e governança ambiental: um resgate teórico. Revista de Ciências Gerenciais, v. 13, n. 18, p. 177-194, 2010.

IBEG - INSTITUTO BRASILEIRO DE GEOGRAFIA E ESTATÍSTICA. Cidades. Disponível em: <https://cidades.ibge.gov.br/brasil/rj/rio-de-janeiro/panorama $>$. Acesso em 28 de ju- 
lho de 2019.

INOUE, C. Y. A. Governança global do clima: proposta de um marco analítico em construção. Rev. Carta Inter., Belo Horizonte, v. 11, n. 1, p. 91-117, 2016.

IPCC. Climate Change 2007: Mitigation. Contribution of Working Group III to the Fourth Assessment Report of the Inter- Governmental Panel on Climate Change [METZ, B.; DAVIDSON, O. R.; BOSCH, P. R.; DAVE, R.; MAYER, L. A. (eds)], Cambridge University Press, Cambridge, United Kingdom and New York, NY, USA, 2007.

IPCC. Climate Change 2014: Impacts, Adaptation and Vulnerability. Contribution of Working Group II to the Fifth Assessment Report of the Intergovernmental Panel on Climate Change. United Kingdom and New York, 2014.

JACOBI, P. R.; SULAIMAN, S. N. Governança ambiental urbana em face das mudanças climáticas. Revista USP, São Paulo, n. 109, p. 133-142, 2016.

KOSTKOVA, P., SZOMSZOR, M., ST. LOUIS, C. \# swineflu: The use of twitter as an early warning and risk communication tool in the 2009 swine flu pandemic. ACM Transactions on Management Information Systems (TMIS), n. 5, v. 2, p. 1-25, 2014.

LI, A.; CROPANZANO, R.; BAGGER, J. Justice climate and peer justice climate: A closer look. Small Group Research, v. 44, n. 5, p. 563-592, 2013.

LIMA, G. F. C. Educação Ambiental e Mudança Climática: convivendo em contextos de incerteza e complexidade. Ambiente \& Educação, Rio Grande, v. 18, n.1, p. 91-112, 2013.

LOCKWOOD, A. Seeding doubt: how sceptics use new media to delay action on climate change. Conference Paper: Association for Journalism Education 'New Media, New Democracy?', Sheffield, 12 September 2008.

LOPEZ, C. E.; VASU, M.; GALLEMORE, C. Understanding the perception of COVID-19 policies by mining a multilanguage Twitter dataset. arXiv preprint arXiv:2003.10359, 2020.

LOOSE, E. B.; GIRARDI, I. M. T. O Jornalismo Ambiental sob a ótica dos riscos climáticos. INTERIN, v. 22, n. 2, p. 154-172, 2017.

MARTINE, G.; ALVES, J. E. D. Disarray in global governance and climate change chaos. R. Bras. Est. Pop., v. 36, p. 1-30, 2019.

MARTÍNEZ-ALIER, J. M. O ecologismo dos pobres: conflitos ambientais e linguagens de valoração. Tradução: Maurício Waldman. São Paulo: Contexto, 2007.

MILANEZ, B.; FONSECA, I. F. F. Justiça Climática e eventos climáticos extremos: uma análise da percepção social no Brasil. Revista Terceiro Incluído, v. 1, p. 82-100, 2011.

MURPHY, C. et al. Adapting to climate change in shifting landscapes of belief. Climatic Change, v.134, p.101-114, 2016. 
O'NEILL, S.; BOYKOFF, M. The role of new media in engaging the public with climate change. In: WHITMARSH, L.; LORENZONI, I.; O’Neill, S. (Eds.). Engaging the public with climate change: behaviour change and communication, p. 233-251, 2011. DOI: 10.1080/01430750.2011.584705.

PARIKH, J. K. Joint implementation and the north and south cooperation for climate change. International Environmental Affairs, v. 7, n. 1, p. 22-41, 1995.

PORTO-GONÇALVES, C. W. A globalização da natureza e a natureza da globalização. $7^{\text {a }}$ edição. Rio de Janeiro: Civilização Brasileira, 2017.

ROSER, D.; SEIDEL, C. Climate Justice - An Introduction. London and New York: Routledge, 2017.

REBOREDO, J. C.; UGOLINI, A. The impact of sentiment on renewable energy stocks. Energy Economics, n. 76, p. 153-169, 2018.

SEVERYN, A.; MOSCHITTI, A. Twitter sentiment analysis with deep convolutional neural networks. In Proceedings of the 38th International ACM SIGIR Conference on Research and Development in Information Retrieval, Santiago, Chile, August 9-13, 2015, p. 959-962.

STOKER, G. Governance as theory: five propositions. In: Governance- Inernational Social Sciences Journal,1998.

VIOLA, E.; FRANCHINI, M. Sistema internacional de hegemonia conservadora: o fracasso da Rio +20 na governança dos limites planetários. Ambiente \& Sociedade, São Paulo, v. 15, n. 3, p. 1-18, 2012.

VIOLA, E.; FRANCHINI, M.; RIBEIRO, T. L. Sistema Internacional de Hegemonia Conservadora. Governança Global e Democracia na Era da Crise Climática. Editora Anna Blumme. São Paulo, 2013. 
Francisca Marli Rodrigues de Andrade

$\square$ marli_andrade@id.uff.br

ORCiD: https://orcid.org/0000-0001-6450-5911
Submitted on: 12/11/2019

Accepted on: 26/06/2020

2020;23:e02022

\section{Tarssio Brito Barreto}

$\square$ tarssioesa@gmail.com

ORCiD: https://orcid.org/0000-0002-2067-3849

\section{Alen Batista Henriques}

$\square$ alenhenriques@id.uff.br

ORCiD: https://orcid.org/0000-0002-9076-1377

How to cite: ANDRADE, F. M. R.; BARRETO, T. B.; HENRIQUES, A. B. Rio de Janeiro e crise climática: governança, interatividade e construção discursiva no Twitter. Ambiente \& Sociedade. São Paulo, v. 23, p. 1-18, 2020. 


\title{
Rio de Janeiro e crise climática: governança, interatividade e construção discursiva no Twitter
}

\author{
Francisca Marli Rodrigues de Andrade \\ Tarssio Brito Barreto \\ Alen Batista Henriques
}

São Paulo. Vol. 23, 2020

Tema em destaque:

Urbanização, Planejamento e Mudanças Climáticas
Resumo: As chuvas de abril de 2019, na cidade do Rio de Janeiro, foram as mais volumosas das últimas décadas, afetando a vida da população de diferentes formas, incluindo a morte de 10 pessoas. A fragilidade da governança ambiental, nesse território, foi convertida no objetivo de: compreender como o tema 'mudança climática' é tratado no Twitter durante um período e em um território específico, marcado por um evento climático extremo. Metodologicamente, adotamos uma perspectiva da análise temática, cujos dados foram obtidos utilizando a API do Twitter, no ambiente de programação R - um total de 375 mil tweets. Os resultados mais significativos destacam as críticas ao negacionismo climático nas agendas das esferas públicas atuais. Ademais, o uso do Twitter como possibilidade de repolitização e de redemocratização dos espaços de decisão, frente aos cenários de injustiça climática.

Palavras-chave: Rio de Janeiro; Chuvas; Crise Climática; Governança; Twitter.

Como citar: ANDRADE, F. M. R.; BARRETO; T. B.; HENRIQUES, A. B. Rio de Janeiro e crise climática: governança, interatividade e construção discursiva no Twitter. Ambiente $\&$ Sociedade. São Paulo, v. 23, p. 1-17, 2020. 


\title{
Rio de Janeiro y crisis climática: gobernanza, interactividad y construcción discursiva en el Twitter
}

\author{
Francisca Marli Rodrigues de Andrade \\ Tarssio Brito Barreto \\ Alen Batista Henriques
}

São Paulo. Vol. 23, 2020

Tema en Destaque: Urbanización, $\mathrm{Pl}$ anificación y Cambio Climático
Resumen: Las lluvias de abril de 2019, en la ciudad de Rio de Janeiro, fueron las más severas en las últimas décadas, afectando la vida de la población de diferentes maneras, incluyendo la muerte de 10 personas. La fragilidad de la gobernanza ambiental, en este territorio, se ha convertido en el objetivo de: comprender cómo el tema 'cambio climático' es tratado en el Twitter durante un período y en un territorio específico, marcado por un evento climático extremo. Metodológicamente, adoptamos una perspectiva de análisis temático, cuyos datos se obtuvieron utilizando la API de Twitter, en el ambiente de programación R - un total de 375 mil tweets. Los resultados más significativos destacan la crítica al negacionismo del cambio climático en las agendas de las esferas públicas actuales. Además, el uso del Twitter como una posibilidad de repolitización y redemocratización de espacios de decisión, ante los escenarios de injusticia climática.

Palabras-clave: Rio de Janeiro; Lluvias; Crisis Climática; Gobernanza; Twitter.

Como citar: ANDRADE, F. M. R.; BARRETO; T. B.; HENRIQUES, A. B. Rio de Janeiro y crisis climática: gobernanza, interactividad y construcción discursiva en el Twitter. . Ambiente $\&$ Sociedade. São Paulo, v. 23, p. 1-17, 2020. 